Naming Infinity 



\section{Naming Infinity}

A True Story of Religious Mysticism and Mathematical Creativity

\section{LOREN GRAHAM and \\ Jean-Michel Kantor}

The Belknap Press of

Harvard University Press

Cambridge, Massachusetts

London, England

2009 
Copyright $\left({ }_{0} 2009\right.$ by the President and Fellows of Harvard College

All rights reserved

Printed in the United States of America

Library of Congress Cataloging-in-Publication Data

Graham, Loren R.

Naming infinity: a true story of religious mysticism and mathematical creativity/Loren Graham and Jean-Michel Kantor.

p. $\mathrm{cm}$.

Includes bibliographical references and index.

ISBN 978-o-674-03293-4 (alk. paper)

I. Mathematics—Russia (Federation)—Religious aspects.

2. Mysticism-Russia (Federation)

3. Mathematics_Russia (Federation)—Philosophy.

4. Mathematics-France-Religious aspects.

5. Mathematics-France-Philosophy. 6. Set theory.

I. Kantor, Jean-Michel. II. Title.

QA27.R8G73 2009

510.947'0904-dc22 200804I334 